\title{
Phonetic Features of Sound-Copying Words Based on the Archival Materials
}

\author{
Mainisa Koshueva1, Elmira Abduvalieva², Dinara Yzabekova ${ }^{3}$, Begimai Nadilbek kyzy4, \\ Aibek Mamasadykov³, Ibraim Abduvaliev5, Zhypargul Abdullaeva6* (1)
}

\author{
${ }^{1}$ Department of Kyrgyz Linguistics, Osh State University, Osh, Kyrgyzstan \\ ${ }^{2}$ Humanitarian disciplines Cycle, Kyrgyz-Uzbek University, Osh, Kyrgyzstan \\ ${ }^{3}$ Department of Philological Education Cycle, Industrial Pedagogical College, Osh State University, Osh, Kyrgyzstan \\ ${ }^{4}$ College of Humanities and Technologies, M.M. Adyshev Osh Technological University, Osh, Kyrgyzstan \\ ${ }^{5}$ Department of Kyrgyz Language, Jalal-Abad State University, Jalal-Abad, Kyrgyzstan \\ ${ }^{6}$ Science and Research Department, Osh State University, Osh, Kyrgyzstan \\ Email: *jypar.science@oshsu.kg
}

How to cite this paper: Koshueva, M., Abduvalieva, E., Yzabekova, D., Nadilbek kyzy, B., Mamasadykov, A., Abduvaliev, I., \& Abdullaeva, Z. (2020). Phonetic Features of Sound-Copying Words Based on the Archival Materials. Open Journal of Modern Linguistics, 10, 665-674.

https://doi.org/10.4236/ojml.2020.106041

Received: October 24, 2020

Accepted: November 17, 2020

Published: November 20, 2020

Copyright (c) 2020 by author(s) and Scientific Research Publishing Inc. This work is licensed under the Creative Commons Attribution International License (CC BY 4.0).

http://creativecommons.org/licenses/by/4.0/

\begin{abstract}
This article is investigating sound composition of the onomatopoeic words in the Kyrgyz language from synchronous and diachronic aspects. Phonetic features and the order of sounds in the words composition were studied. Content of archival materials for creation of a dictionary of onomatopoeic words is discussed. The purpose of this work is to study the use of vowels and consonants in speech and the words mimicry of Kyrgyz language. Linguistic phenomenon is important in enriching the vocabulary of particular language; for this purpose, archival materials on the active use of vowels and consonants in different positions of onomatopoeic words were described.
\end{abstract}

\section{Keywords}

Onomatopoeic Words, Vowels, Consonants, Vowel Longitude, Consonant Longitude, Phonetic Features, Sound Copying

\section{Introduction}

Perception of speech is one of the most fascinating attributes of human behavior, because both the auditory periphery and higher centers help define the parameters of sound perception (Pisoni, 1985). As it is known, the sounds of speech do not have their own meaning, but are used to distinguish words. Speech perception also can be viewed from the listener's integration of two sources of information: 1) the acoustic features transduced by the auditory receptor system and 2) context of the linguistic message (Massaro \& Cohen, 1983). The phonological or 
functional approach to the study of speech sounds plays a leading role in the modern linguistics (Joseph, 1992). Different quality of sounds was explained by the different places in which these sounds are occupying in composition of words. In addition, when pronouncing words, one sound can affect the quality of another, as a result of which the qualitative character of the sound is determined by the position of the sound-a preposition, postposition or interposition (Mbarki et al., 2019). Onomatopoeia is defined as involving the use of words imitating sounds (Sasamoto \& Jackson, 2016; Laing, 2017). Onomatopoeic words of the Kyrgyz language are constituted of a special layer of vocabulary. The use of onomatopoeic words in the works is shown in examples from the first volume of the epos "Manas" (Kongyratbay et al., 2014). Since the volume of the article is not allowed, it was not possible to include all the examples with the corresponding sounds. Root onomatopoeic words (Monaghan et al., 2014) most often appear in the form of monosyllabic complexes consisting of two-, three-sound closed syllables.

Additional shades of meaning were conveyed by adding consonants or syllables to the root words. Such an interesting linguistic phenomenon played a large role in enriching the vocabulary of language, but nature of words requires further study. For this purpose, archival materials of the famous "red professor" $\mathrm{K}$. Tynystanov are of great importance. K. Tynystanov worked on the active use of vowels and consonants in different positions of onomatopoeic words in the $1930^{\text {th }}$ of the $20^{\text {th }}$ century, compiled dictionaries containing over one hundred thousand words on these features. Study and analysis of the vocabulary of the Kyrgyz exposes allowed us to note that in the text of the epos there is an abundance of onomatopoeic words. Omission, addition, or substitution of data for sounds involved in the formation of words contributed to an increase in the number of onomatopoeic words and played a large role in enriching the artistic properties of epos. The vowels of the Kyrgyz language such as "a" and "o" are actively used at the beginning of the words. From the 8 vowel sounds, 7 were involved, and 155 words were formed. In contrast to the use in full-valued words, consonants in onomatopoeic words have the ability to be used in all positions of the word compositions in colloquial and artistic styles. According to the materials of $\mathrm{K}$. Tynystanov dictionaries, it can be noted that sounds can serve as the main basis for structuring parts of speech, especially onomatopoeic words occupy a special place in the formation of figurative verbs. Study of speech sounds (Cheung et al., 2016) example is represented in Figure 1; from this point of view statistical accounting is an invaluable material for the compilation of dictionaries the opposite, frequency, synonyms, antonyms, homonyms, etc.

\section{Materials and Methods}

Research methods were characterized by a combination of the empirical methods (observation, measurement, and experiment) and elements of the structural-semantic and comparative-typological principles of analysis (Forkel et al., 2018). 


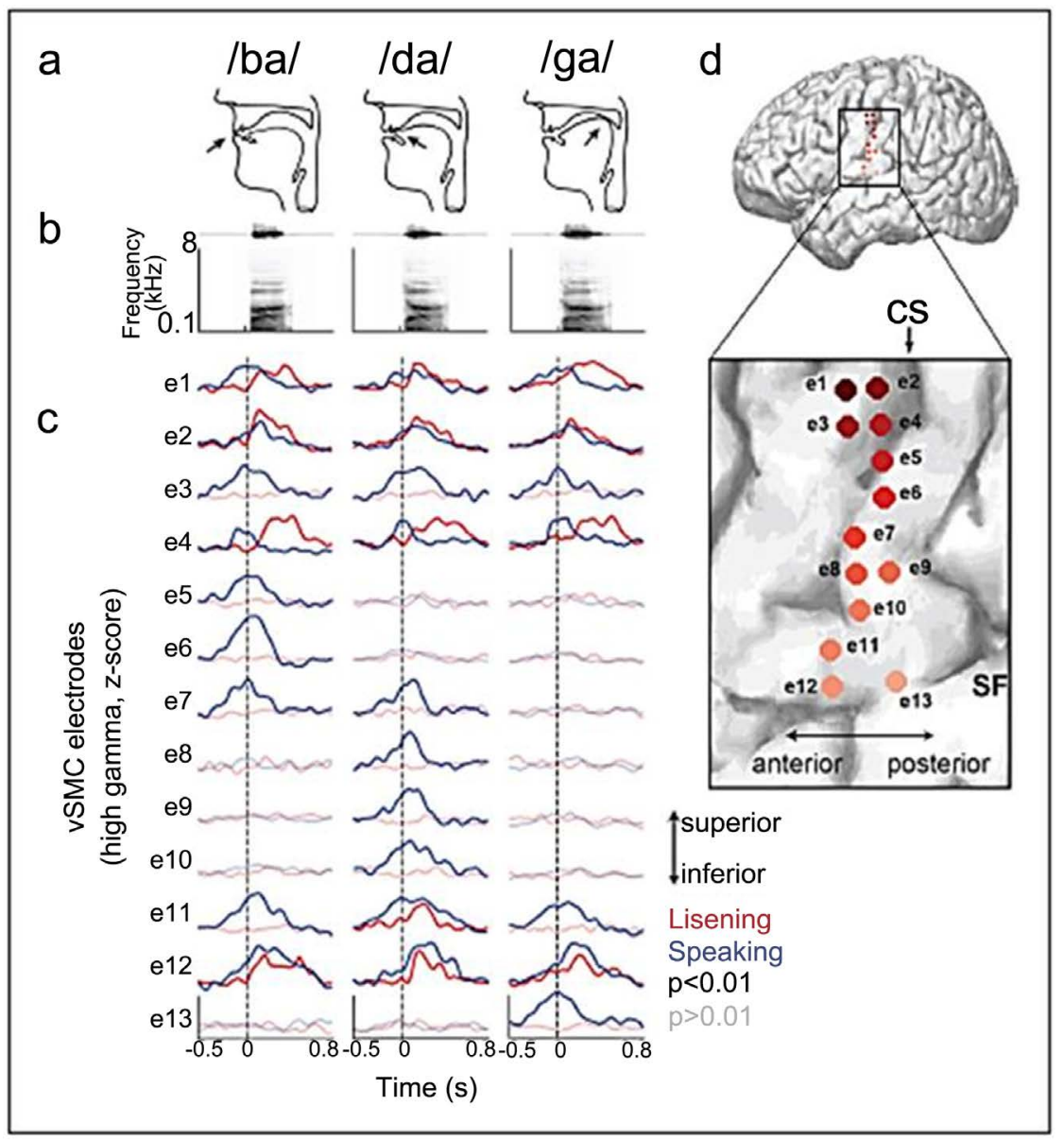

Figure 1. Site-by-site differences in vSMC neural activity when speaking and listening to CV syllables. (a) Top, vocal tract schematics for three syllables (/ba/, /da/, /ga/) produced by occlusion at the lips, tongue tip, and tongue body, respectively (arrow). (b) Acoustic waveforms and spectrograms of spoken syllables. (c) Average neural activity at electrodes along the vSMC for speaking (blue) and listening (red) to the three syllables (high gamma $z$-score). Solid lines indicate activity was significantly different from pre-stimulus silence activity $(p<0.01)$. Transparent lines indicate activity was not different from pre-stimulus silence activity $(p>0.01)$. Vertical dashed line denotes the onset of the syllable acoustics $(\mathrm{t}=0)$. (d) Location of electrodes 1 - 13 in panel $c$, shown on whole brain and with inset detail. $\mathrm{CS}=$ central sulcus, $\mathrm{SF}=$ Sylvian fissure (Cheung et al., 2016).

A comparative typological analysis of the sound composition of onomatopoeic words from an epos and from a modern language makes it possible to summarize the richest material. The structural-semantic approach allows us to study the internal structure of objects of this study.

When considering the onomatopoeic words of the Kyrgyz language in the synchronous and diachronic aspects or when studying their phonetic features, the order of sounds in the composition of words is of great importance. Occupation of various positions by vowels and consonants enhances the meaning of onomatopoeic words. More precisely, their advantage in sound composition revealed in comparison with the full meaning words. In order to observe the use of onomatopoeic words in various works, we choose the first volume of the epic 
"Manas". They presented only to show how these examples were calculated. Therefore, firstly we pay attention to the sound features of onomatopoeic words used in the scientific literature and in everyday life.

\section{Results and Discussions}

\subsection{Consonants at the Beginning of a Word and at the End of a Word}

When analyzing the use of consonant sounds at the beginning of a word and at the end of a word, sounds should be analyzed taking into account their sonorousness, deafness and sonority:

1) At the beginning of the word, almost all deaf consonants are actively used, except for consonant sounds ц, щ: к (ы), к, (и), п, с, т, ф, х, ч, ш; as well as all voiced consonants, except for ж (журнал): 6, в г, д. ж, 3; from the number of sonorific sounds $\mathrm{M}, \pi$, are actively used, while sound $и$ is used rarely.

2) The use of consonant sounds at the end of a word is also necessary at the beginning of a word. This has a definite advantage, since there are cases when use of sounds ц, щ, ж (журнал), almost do not occupy a preposition. In addition, there are cases of using isolated sounds such as e, ю, я, not typical for the Kyrgyz language. They can be used in the Kyrgyz language in the form of ya, yo, yu, but to imitate a cat or to utter exclamations when practicing the karate or kung fu. Russian versions of these sounds are used, which contributes to a more accurate pronunciation or imitation.

In contrast to the use in full valued words, consonants in onomatopoeic words have the ability to be used in all positions of the word composition in colloquial and artistic styles.

\subsection{Vowels at the Beginning of a Word and at the End of a Word}

1) Vowel sounds are fully used at the beginning of the word are: ay (ay), ars (apc), alang-bulang (алаң-булаң), iz-iz (ыз-ыз), uu-chuu (уу-чуy), opur-topur (опур-топур), elen-elen (элең-элең), ouk (өк), oupon (өпөң), илең-салаң (ilen-salan), ouf (үөф), urpon (үрпөң), etc. Moreover, their long variants can be used with unusual longitude for stylistic purposes: aa-yy (aа-uu), ooy (оой), etc. This fact of long vowels is often used in the colloquial and artistic styles.

2) Vowels are freely used at the end of a word. The possibility of using both short and long vowels is wide: ha-ha (ха-ха), kyroo-kyroo (кыроо-кыроo), me-mee (мэ-мээ), churu-chuu (чуру-чуу), hee-hee (хи-хи,), kazhy-kuzhu (кажы-кужу), etc.

As mentioned above, onomatopoeic words were calculated by using the vowels and consonants, among them at the beginning and at the end of a word using the example cited in the scientific literature, based on which a table they were compiled. Each language in its sound capabilities is trying to imitate natural sounds, as accurately as possible. A single sound or exclamation may have uniform repeatability or with changes, as well as qualities such as clarity, 
strength, pitch, clarity, tightness, deafness, weakness, etc. In our opinion, it can be argued that almost all vowels and consonants can be used in all positions of onomatopoeic words. Since when using an onomatopoeic word (it is necessary to take into account nationality, age, living environment, creativity, speech situation and other characteristics of the consumer), the speaker uses the appropriate sounds to convey this or that imitation, image, feeling, etc. This problem was also noted in the writings of scientists: "... any onomatopoeic word can be used, the sound composition of which corresponds to" (Abduvaliev \& Sadykov, 1997; Ashirbaev, 2000). “... it is impossible to reproduce in speech the sounds produced by objects in the form in which they are. Onomatopoeic words are able to imitate sounds only approximately" (Abduvaliev \& Sadykov, 1997). Therefore, in the sound composition of onomatopoeic words, the vowels and consonants can be found, since, they are using both at the beginning, in the middle and end of the word. The sound as a complex of onomatopoeic words does not have such an opportunity as full meaning words have, but sometimes they even have an advantage (Paice, 2016). It should be noted that although full-meaning words can consist of vowels and consonants. Scientists rightly noted that onomatopoeic words have such an advantage: "Individual onomatopoeic words used in the speech are appearing not as words, but as a sound complex. The values of these sound means are interpreted by means of sentences: "Um, balakatka jetip kalgan tura, bechara ... (Um, it turns out, has already come of age, poor ...); Biy... dep akyryn kep bashtady, al akyryn oydo bolup, $\mathrm{mm}$, ... el sizdiki, bul oorchuluk sizge da salmagyn saldy ... Alar uchun tfu degen bir tukuruk. Anan kalsa bizdi aerge takyr kirgizbeyt" (Biy ... began a conversation quietly, rising from his place-Ahem ... your people, this burden fell on you too ... And they will never let us enter there). In the above examples, the author conveyed the state of the hero who is not daring to say something. He used the phonetic lumps "um, ahem", explaining the clamped, deaf, weak sounds (exclamations). And in the second sentence, through "tfu", he expressed the concept of "don't give a damn".

$K$. Tynystanov had noted the active use of vowels and consonants in different positions of onomatopoeic words in the $30^{\text {th }}$ of the twentieth century, compiled dictionaries containing over one hundred thousand words on these features. It should be noted that from the materials of dictionaries it can be noted that they can serve as the main basis for structuring parts of speech; especially onomatopoeic words occupy a special place in the formation of figurative verbs.

As an example, let us turn to the second book, which contains the smallest number of words of 160 . This book includes 1178 onomatopoeic words and here the number of words was calculated according to the position of the vowels at the beginning of the word: A-39, B-200, B-no, G-no, D-83, E-no, E (yo)-no, Zh-51, Z-38, I-9, K-283, L-6, M-13, N-no, H-no, O-24, Ө-4, P-no, R-no, S-46, T-144, U-7, Y-9, F-no, X-no, Ts-no, Ch-110, Sh-67, Shch-no, Y-20, E-20, Yu-no, I-no. Total number of words is 1178 . In the dictionaries of $\mathrm{K}$. Tynystanov dedicated to onomatopoeic words under inventory numbers 159, 1-2 books; 160, 1-2 books; 161, 1-2 books; 162, 177, 178, 179, 180, 181, 182, it was found that all the 
onomatopoeic words that are used today. Therefore, we can be sure that the scientist tried to collect all onomatopoeic words, starting from the time of our ancestors and to pass on to subsequent generations. Since he knew the properties of imagery and the artistic power of these words, he especially emphasized the onomatopoeic root verbs of imagery. In the expression of these properties of onomatopoeic words, their sound appearance is important, which is confirmed by examples from the epic "Manas".

Table 1 shows the activity of consonants in use at the beginning of the word. Words in which the named sounds participate were chosen from the epic as follows. The sound that is most used in the epic: K (s) kaldayup (p.29), kilaytyp (p.29), kulzhundashyp (p.29), koluytup (p.30), kuluyndap (p.30), kylactagan (p.31), kaldaytkan (p.34), karkyldap (p.36), kykyldagan (p.36), karkaytip (p.37), kaykalatpay (p.38), kyzyldagan (p.41), kazyldagan (p.41), kilayyp (p.41), koykoitup (p.55), karsyldashyp (p.56), kaldyrap (p.60), karkaigan (p.63), koroktop (p.64), kyykyryp (p.65), kylytyp (p.69), koroktop (p.71), kyykyrygy (p.71), kuluzhdashyp (p.72), kakaydym (p.74), cornettogon (p.76), kyyshandatpay (p.80), kars etse (p.80), karch (p.81), kylkyldap (p.82), kaldaytyp (p.83), karkaigan (p.83), kylkyldap (p.86), kazh-kuzh etip (p.89), kyzyldap (p.89), kyzyldagan (p.90), kykyrsa (p.91), kakaydym (p.91), korkurap (p.94), karsyldap (p.95), kilt etpei (p.96), kyltayyp (p.97), kurkurop (p.98), karsyldashyp (p.98), kachyr-buchur (p.102), kakaylap (p.103), karsyldashyp (p.103), karkyldap (p.113), kalkayyp (p.113), karsyldashyp (p.116), kazyldagan (p.116), kakaylap (p.118), kyzhyldagan (p.120), kultuytup (p.124), kykyldap (p.125), kyzyldap (p.127), kykyldap (p.129), kogurap (p.136), kykyldap (p.136), kaykalatpay (p.138), konzhodop (p.140), koroktop (p.141), kyzhyldap (p.141), calnettop (p.142), kaldaktap (p.142), kaldai (p.142),

Table 1. Total consonants used at the beginning of words.

\begin{tabular}{cccccccc}
\hline \multicolumn{2}{c}{$\begin{array}{c}\text { Voiced } \\
\text { consonants }\end{array}$} & \multicolumn{2}{c}{ Number of } & \multicolumn{2}{c}{ Deaf } & \multicolumn{3}{c}{ Number of Sonorific Number of } \\
words & consonants & words & consonants & words
\end{tabular}


caldailar (p.142), kyzhyldagan (p.142), kakayip (p.144), kakayyp (p.144), caldailar (p.144), kalkyldap (p.147), korkytup (p.148), kyzhyldap (p.151), kazhyldag (p.151) (Aitmatov, 1984).

Then the second place occupied by ч (ch), from voiced д (d), ж (hz), з (z) and other sounds. Thus, the space for consonant sounds at the beginning of a word is quite wide. According to our estimates, the table has 518 onomatopoeic words that begin with 12 consonants. Here you can find that there are no onomatopoeic words beginning with all 13 consonants: voiced $\mathrm{B}, \mathrm{F}, \mathrm{\Gamma}$, ж, from deaf $\Pi, \phi, \mathrm{x}$, ц, щ, from sonorous $\mathrm{H}, \mathrm{p}, \mathrm{H}$, й. There are no onomatopoeic words beginning with sonorific ң, й. We summed up taking into account our mistake, namely, that we could not analyze the second book of the epic "Manas". If we conduct a statistical analysis of the entire text of the epic, we would notice that consonants actively participate at the beginning of a word. This opinion is assumed by the fact that during the search for examples from the text (epic), it can be found that a number of onomatopoeic words were used. Such thorough research is a matter of the future.

\subsection{Consonants at the End of a Word}

As can be seen from Table 2, according to the use of consonant sounds at the end of a word, some sounds in the epic are not used (only according to the first book). As noted in the scientific literature regarding the use of consonants at the end of a word, "at the end of a word, the longitude of slotted 3, p, с, ж, ш, ң: гүр-p (gur-r), шар-p (shar-r) and etc. In such cases, repeatability or publicity is emphasized. This can be found in the following comparisons: "bysh et||bysh-bysh et||bysh-sh et." and "dan et||dan-dan et||dan-n et.". In fact, the double or triple use of consonant sounds at the end of a word gives the onomatopoeic word a different meaning: most often, they emphasize the intensity and longitude of the action.

Table 2. General summary of consonants at the end of a word.

\begin{tabular}{|c|c|c|c|c|c|c|}
\hline & $\begin{array}{c}\text { Voiced } \\
\text { consonants }\end{array}$ & $\begin{array}{c}\text { Number of } \\
\text { words }\end{array}$ & $\begin{array}{c}\text { Deaf } \\
\text { consonants }\end{array}$ & $\begin{array}{c}\text { Words } \\
\text { quantity }\end{array}$ & $\begin{array}{c}\text { Sonorific } \\
\text { consonants }\end{array}$ & $\begin{array}{c}\text { Words } \\
\text { quantity }\end{array}$ \\
\hline & 6 & 19 & қ (ы) & 7 & $\mathbf{M}$ & \\
\hline & B & - & к (и) & & л & \\
\hline & г (ы) & - & $\Pi$ & 9 & $\mathrm{H}$ & \\
\hline & г (и) & - & c & & $\mathrm{p}$ & 16 \\
\hline \multirow[t]{5}{*}{ Consonant sounds } & ж & 5 & $\mathrm{~T}$ & & Н & 13 \\
\hline & 3 & & $\phi$ & & й & 3 \\
\hline & & & $\mathrm{x}$ & & & \\
\hline & & & ч & 3 & & \\
\hline & & & ш & & & \\
\hline Number of words & & 5 & & 19 & & 32 \\
\hline Sound & & 1 & & 3 & & 3 \\
\hline
\end{tabular}




\subsection{Vowels at the Beginning of a Word}

As it is shown in Table 3, the sounds "a" and "o" are actively used at the beginning of the word. From the 8 vowels in the Kyrgyz language alphabet, 7 are involved in formation of 155 words.

Summarizing above, it should be noted that in the text of the epic there is an abundance of onomatopoeic words. The omission, addition, or substitution of data for sounds involved in the formation of words contributed to an increase in the number of onomatopoeic words and played a large role in enriching the artistic properties of the epic.

For example, "Ordodon chygyp okongdop, Aikol Manas artynan, Ar kimisi kyrk choro, Ala-Toodoy zonkondop" (They came out of the horde hefty and overweight, behind Manas the magnificent, each of the forty choro like Ala-Too huge, awkward). In these lines of onomatopoeia, zonkondop is differing in only one sound, but the first (onkondop) depicts the health of the baatyrs (heroes) leaving the village, and the second (zonkonop) compares each of the forty choro associates of Manas with a huge mountain Ala-Too. This word expresses the entire heroic volume in epic.

The position of the person speaking with the help of the right word is given to the other side in an imaginative, figurative way and has an emotional-expressive effect on the listener. This can be found in the stories of the epic "Manas" from the beginning to the end of the work. For example, the dream of the richman Jakyp when he was childless, the interpretation of dreams, naming a child when he had a child, giving a gift to a newborn child (which exists in Kyrgyz people culture), Koshoi's blessing to Kanykei, etc. rituals. That is why there is a proverb, "Blessing makes the people grown, and rain makes the earth green." In the epic, tradition [custom [habit [chronicle, ceremony, ritual [custom, norm, [rule, etc.]

Table 3. Vowels at the beginning of a word.

\begin{tabular}{|c|c|c|c|c|c|c|c|c|}
\hline $\begin{array}{l}\text { Vowel } \\
\text { sounds }\end{array}$ & $\begin{array}{c}\text { Word } \\
\text { quantity }\end{array}$ & $\begin{array}{c}\text { Deaf } \\
\text { consonants }\end{array}$ & $\begin{array}{c}\text { Word } \\
\text { quantity }\end{array}$ & $\begin{array}{c}\text { Voiced } \\
\text { consonants }\end{array}$ & $\begin{array}{c}\text { Word } \\
\text { quantity }\end{array}$ & $\begin{array}{c}\text { Sonorific } \\
\text { consonants }\end{array}$ & $\begin{array}{l}\text { Word } \\
\text { quantity }\end{array}$ & Total \\
\hline A & 84 & к (ы) & & 6 & 184 & M & - & \\
\hline Э & 6 & к (и) & & B & - & л & 1 & \\
\hline $\mathrm{O}$ & 37 & $\Pi$ & - & $\mathbf{r}$ & - & H & - & \\
\hline$\theta$ & 9 & c & 40 & $\mathbf{r}$ & - & $\mathrm{p}$ & - & \\
\hline Ы & 7 & $\mathrm{~T}$ & 40 & д & 67 & ң & - & \\
\hline И & - & $\phi$ & - & ж & 36 & й & - & \\
\hline $\mathrm{y}$ & 3 & $\mathrm{x}$ & - & 3 & 25 & & & \\
\hline Y & 9 & ч & & & & & & \\
\hline Sounds & 7 & 3 & 26 & 4 & & 1 & & 15 \\
\hline $\begin{array}{c}\text { Total } \\
\text { number } \\
\text { of words }\end{array}$ & 155 & & 106 & & 312 & & 15 & 575 \\
\hline
\end{tabular}


is a clear, concise, imaginative expression of national color. The role of vowels and consonants is great, as the artist serves as a stylistic tool.

Although some imitation words look like completely important in terms of their phonetic form, they can become homonyms for proverbs, such as baa, taka-tak, chyk-chyk, shak, zan, top, shar, and so on. The meanings of these words are baa (assessment), taka (podkova; kabluk), tak (spot; exactly), chyk (get out; broth, etc.), shak (branch, branch; pola rosa), zan (kal, navoz), top (ball; collective), shar (air balloon), and the meanings of the imitation words are baa (when crying, fear), taka-tak (knock-knock), chyk-chyk (sound of the clock), shak (tuk-tuk); stuk da stuk), zan (sound of iron blow), ball (when an apple falls), shar (sound of water), etc.

\section{Conclusion}

The analysis of the sound composition of onomatopoeic words from the first volume in the epic "Manas" showed the following:

1) In contrast to the use of full valued words, consonants in onomatopoeic words can be used in all positions of the word composition in texts of colloquial and artistic styles.

2) The activity of consonants at the beginning of a word is noted. The space for consonants at the beginning of a word is quite wide. According to our estimates, there are 518 onomatopoeic words starting with 12 consonants. Here you can find that there are no onomatopoeic words beginning with all 13 conso-

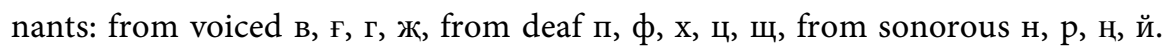
There are no onomatopoeic words beginning with sonorific ң, й.

3) Due to the large volume of research work, we were unable to analyze the second book of the epic "Manas". If we conduct a statistical analysis of the entire text of the epic, then one would notice that consonants are actively involved at the beginning of a word. This opinion is assumed by the fact that in the course of searching for examples from the text (epic), one can find that a number of onomatopoeic words are used. However, such a thorough investigation is a matter of the future.

Thus, the phonetic features of onomatopoeic words play a huge role in both oral and written speeches.

The practical significance in this work is related to scientific findings in education of preschool children, their environment, natural phenomena, animals, etc., which are used in cognition, in teaching by imitating the sounds coming from surrounding environment, in understanding the ethical and aesthetic values of characters, events and phenomena; and in the works read by the students. Practical importance helps in learning the foreign languages, because sounds can be used both individually and repeatedly, to imitate the sounds and images of various phenomena in the environment. Therefore, the order of vowels and consonants is also free, that is, the word can be used at the beginning, middle, and end. When using proverbs and sounds that are similar not only to the Kyr- 
gyz language, but also to the sounds of other languages they can be imitated (for example, "waw”, “av", "av-av", "wav", “fu”, “ya”, etc.), therefore, forms flexibility in learning foreign languages should be considered.

\section{Conflicts of Interest}

The authors declare no conflicts of interest regarding the publication of this paper.

\section{References}

Abduvaliev, I., \& Sadykov, T. (1997). Azyrky Kyrgyz tyli: Morphologya, Bishkek (296 p.).

Aitmatov, Ch. (1984). Epos Manas. Sayakbay Karalaevs version (500 p.). Frunze: Kyrgyzstan.

Ashirbaev, T. (2000). Kyrgyz tilinin stylistikasi: Phonetikalyk, soz jasoo jana lexikalyk stylistika (2nd ed., 172 p.). Bishkek.

Cheung, C., Hamiton, L. S., Johnson, K., \& Chang, E. F. (2016). The Auditory Representation of Speech Sounds in Human Motor Cortex. eLife, 27, e17181.

https://doi.org/10.7554/eLife.12577.018

Forkel, R., List, J., Greenhill, S., Rzymski, C., Bank, S., Cysouw, M., Hammarström, H., Haspelmath, M., Kaipin, G. A., \& Gray, R. D. (2018). Cross-Linguistic Data Formats, Advancing Data Sharing and Re-Use in Comparative Linguistics. Scientific Data, 5, Article ID: 180205 . https://doi.org/10.1038/sdata.2018.205

Joseph, J. E. (1992). Modern Linguistics in Post-Modern Perspective. Language \& Communication, 12, 165-179. https://doi.org/10.1016/0271-5309(92)90006-U

Kongyratbay, T., Kamak, A., \& Kongyratbay, K. (2014). Epos Is an Ethnic Source. International Journal of Scientific \& Technology Research, 3, 29-32.

Laing, C. E. (2017). A Perceptual Advantage for Onomatopoeia in Early Word Learning: Evidence from Eye-Tracking. Journal of Experimental Child Psychology, 161, 32-45. https://doi.org/10.1016/j.jecp.2017.03.017

Massaro, D. W., \& Cohen, M. M. (1983). Phonological Context in Speech Perception. Perception \& Psychophysics, 34, 338. https://doi.org/10.3758/BF03203046

Mbarki, S., Mourchid, M., \& Silberztein, M. (2019). Formalizing Natural Languages with NooJ and Its Natural Language Processing Applications. International Conference on Automatic Processing of Natural-Language (p. 811, 251 p.). Berlin: Springer International Publishing, Springer Nature Switzerland AG.

https://doi.org/10.1007/978-3-319-73420-0

Monaghan, P., Shillcock, R. C., Christiansen, M. H., \& Kirby, S. (2014). How Arbitrary Is Language? Philosophical Transactions of the Royal Society of London. Series B, Biological Sciences, 369, Article ID: 20130299. https://doi.org/10.1098/rstb.2013.0299

Paice, C. D. (2016). Lexical Analysis of Textual Data. In L. Liu, \& M. Özsu (Eds.), Encyclopedia of Database Systems (4355 p.). New York: Springer. https://doi.org/10.1007/978-1-4899-7993-3_941-2

Pisoni, D. B. (1985). Speech Perception: Some New Directions in Research and Theory. The Journal of the Acoustical Society of America, 78, 381-388. https://doi.org/10.1121/1.392451

Sasamoto, R., \& Jackson, R. (2016). Onomatopoeia-Showing-Word or Saying-Word? Relevance Theory, Lexis, and the Communication of Impressions. Lingua, 175-176, 36-53. https://doi.org/10.1016/j.lingua.2015.11.003 